\title{
Reduction of the urban cooling effects of an intensive green roof due to vegetation damage
}

\author{
A.F. Speak ${ }^{\mathrm{a}, *}$, J.J. Rothwell ${ }^{\mathrm{a}}$, S.J. Lindley ${ }^{\mathrm{a}}$, C.L. Smith ${ }^{\mathrm{b}}$ \\ ${ }^{a}$ Geography, School of Environment and Development, The University of Manchester, Arthur Lewis Building, Oxford Road, \\ Manchester M13 9PL, UK \\ ${ }^{\mathrm{b}}$ College of Science and Engineering, University of Leicester, Bennett Building, University Road, Leicester LE1 7RH, UK
}

\section{A R T I C L E I N F O}

\section{Article history:}

Received 11 November 2012

Received in revised form 15 January 2013

Accepted 30 January 2013

\section{Keywords:}

Green roof

Urban heat island

Microclimate

\begin{abstract}
A B S T R A C T
Green roofs are increasingly being utilised as urban climate adaptation measures given good evidence of their passive cooling effects. Shading of conventional building surfaces, higher albedo and latent cooling from evapotranspiration mean that vegetated surfaces can be used to significantly lower surface and air temperatures in cities. The extent to which cooling properties may be affected by poor maintenance, green roof damage and the general health of the vegetation is not as well known. This study investigates the ability of an intensive green roof in Manchester, UK, to cool the air above it relative to an adjacent conventional, concrete roof. The monthly median air temperature was found to be $1.06{ }^{\circ} \mathrm{C}$ lower at $300 \mathrm{~mm}$ over the green roof. Diurnal trends were apparent, with strongest cooling of $1.58{ }^{\circ} \mathrm{C}$, occurring at night when Urban Heat Islands are most common. A section of green roof was damaged by mismanagement in a drought period, which allowed an investigation into the impairment to the cooling effect when large areas of bare substrate are present. Daytime temperatures were higher over this section of the roof than over an adjacent healthy green roof, being a maximum $0.63^{\circ} \mathrm{C}$ warmer than the bare roof on average, in the late morning. Cooling still occurred at night, albeit with a lower maximum average relative cooling of $0.78{ }^{\circ} \mathrm{C}$. Implications of the spatial influence of green roof cooling are discussed along with the need to undertake careful maintenance and irrigation of the roofs for the benefits to be maintained.
\end{abstract} (c) 2013 Elsevier Ltd. All rights reserved.

\footnotetext{
* Corresponding author.

E-mail address: andrew.speak@postgrad.manchester.ac.uk (A.F. Speak).
} 


\section{Introduction}

Green roofs have been widely researched to assess their role as adaptation strategies for high urban temperatures using both empirical (Köhler et al., 2003; Spolek, 2008; Teemusk and Mander, 2009), and modelling studies (Barrio, 1998; Niachou et al., 2001; Alexandri and Jones, 2007). The need to ameliorate the Urban Heat Island (UHI) effect is given added importance when the effects of climate change are factored into high urban temperatures. An increase in the frequency of summer heat wave events (Murphy et al., 2009) implies that UK urban areas could become thermally uncomfortable places to live in the future. The European heat wave of 2003 claimed an estimated 70,000 lives (Robine et al., 2008), of which over 2000 were in England and Wales (Larsen, 2006). A large number of the fatalities were located in urban areas due to the high population densities there, with half the world's population living in cities (UN, 2009), and also due to the nature of the built environment.

Urban areas are abundant in materials with a high thermal capacity such as concrete and asphalt (Taha, 2004). This along with anthropogenic thermal inputs (Smith et al., 2009) and urban canyon effects (Landsberg, 1981), is one of the contributors towards the UHI phenomenon, whereby cites in the UK can be up to $7^{\circ} \mathrm{C}$ warmer than adjacent rural areas (Wilby, 2008). Conventional urban surfaces are also distinctly lacking in evapotranspiring surfaces leading to differences in the partitioning of shortwave radiation in an energy budget (Oke, 1982). A lack of vegetated surfaces means less incoming solar energy is used for latent cooling. It can be argued that UHIs are currently not as big a problem for UK cites as for other international cities because they reduce winter heating costs (Landsberg, 1981), but predicted higher temperatures in a future climate may exacerbate summer warm conditions. Additionally, regions presently with cooler average temperatures, such as North West UK, have lower adaptation thresholds, in terms of high temperature-mortality relationships (Armstrong et al., 2011).

High temperatures can occur in areas home to vulnerable populations causing an increase in the risk of human health impacts in cities (Donaldson et al., 2001; Lindley et al., 2004). When the temperature is close to human body temperature of $37^{\circ} \mathrm{C}$, physiological stress can occur (Larsen, 2003). At the extreme end of the UKCP09 probabilistic predictions there is a 10\% likelihood that the Manchester conurbation will experience temperatures of $20-22^{\circ} \mathrm{C}$ during warm summer nights (Cavan, 2010). It is at night that the effects will be most felt because city residents will be indoors with an associated reduced ability to seek refuge from overheating. Quantifiable climate risk indices were investigated for Manchester (Smith and Lawson, 2012) with threshold exceedance of meteorological variables, such as days with maximum daily temperature greater than or equal to $29.2^{\circ} \mathrm{C}$, found to be indicative of weather-related impacts. In a future UK climate, four more heat wave events per year are predicted, along with a summer rainfall decrease of $17 \%$ (Murphy et al., 2009).

Adaptation to rising temperatures is becoming as important as mitigation of greenhouse gas emissions, and includes techniques such as designing buildings to minimise incident solar gain or increase ventilation (Gupta and Gregg, 2012). Passive cooling from increasing the amount of greenspace in the built environment is increasingly being seen as a beneficial adaptation technique, preferable to increasing reliance on mechanical air conditioning. The latter increases urban electric demand in summer (Akbari et al., 2009) and also contributes to increased greenhouse gas and air pollutant levels from the burning of fossil fuels by electricity-producing facilities to meet this demand (Solecki et al., 2005). Microclimate modification by vegetation is achieved in three ways. Plants shade buildings, and there is a localised increase of latent cooling via evapotranspiration (Solecki et al., 2005) and additionally there may be an increase in solar reflectance due to the higher albedo of leaf surfaces compared to building materials (especially in temperate and cold climates) (Grant et al., 2003).

Green roofs are being utilised increasingly in climate change adaptation strategies and as a means to reduce the costs associated with mechanical air conditioning (Castleton et al., 2010). Large scale roof greening was suggested to have the indirect benefit of a $25 \%$ reduction in urban electricity use by reducing UHIs (Akbari and Konopacki, 2005), on top of direct energy savings for individual buildings (Sailor, 2008). Green roofs have an additional benefit of needing no major upheaval of the existing urban infrastructure in order to accommodate the vegetation. A hindrance to extensive greening of urban centres is the competition for expensive building space and the fact that the fundamental layout of cities is unlikely to change for some years (Wong et al., 2003b). A study into the potential of trees to 
climate-proof Manchester found that the limited space available for tree planting meant that tree cover could only be increased by up to $5.3 \%$, which was not sufficient to keep surface temperatures at current levels even up the 2020s (Hall et al., 2012). A solution is to utilise the available space afforded by rooftops. Estimates of urban rooftop coverage vary greatly but can be as high as $35 \%$ of the land cover (MacMillan, 2004), and 15\% of the city centre area of Manchester is composed of flat roofs that could potentially support a green roof (Speak et al., 2012).

Urban greening schemes often require careful planning and installation, incorporating design techniques to maximise irrigation for instance, and the resulting green space can need certain maintenance procedures. In the case of green roofs this entails regular weeding and irrigation in dry periods. The cooling properties are dependent on the lush vegetation and any impairment to this cover can reveal large areas of soil substrate which can alter the thermal properties of the roof. Data from Wong et al. (2007) indicate surface temperature increases of up to $10^{\circ} \mathrm{C}$ and overlying air temperature increases of around $2{ }^{\circ} \mathrm{C}$ after a new extensive green roof was constructed in Singapore, and incomplete foliage cover was a major reason for this. Bare substrate was also responsible for surface warming on a green roof during warmer months at higher latitudes (Teemusk and Mander, 2010). These studies have brought to light this deleterious effect of the bare substrate and a need for further research into this area is apparent. The shallow substrates of green roofs mean they are prone to drying out, and climate projections for less summer rainfall indicate that drought may become a threat to plant survival if artificial irrigation is not in place. Modelling studies often assume no drought stress on the green roof vegetation component (Gill et al., 2007), so correct parameterisation of the reduced cooling during drought periods will improve green roof modelling capabilities.

The aim of this study is to investigate how the cooling effects of an intensive green roof are affected by adverse conditions. The objectives are thus twofold. Firstly, to quantify the cooling effects of the green roof when compared to an adjacent bare roof. Secondly, to look at how this cooling effect is affected when a combination of mismanagement and drought severely damages the green roof vegetation. In situ monitoring of air temperatures above an aged green roof, can reveal thermal characteristics that will be useful when considering the impact of green infrastructure on UHIs both now, and in the future when climate change projections manifest. A recent meta-analysis by Bowler et al. (2010) revealed that the majority of studies comparing air temperature measurements of green and non-green urban areas were focussed on parks and trees, with green roofs being less studied. Most green roof studies concentrate on surface temperature reductions and subsequent lowered heat transfer into buildings and reduction in cooling loads (Niachou et al., 2001; Sfakianaki et al., 2009). By investigating the effect green roofs have on the local microclimate, this study will provide novel data on how they can aid UHI reduction and improve thermal comfort in cities. Additionally, investigating their performance when damaged can help provide valuable information on how their usefulness within urban greening schemes can be compromised, which is important information for greenspace managers.

\section{Methodology}

\subsection{Site description}

Manchester is a large city in North-West England with a population of 498,000 (MCC, 2010). As one of the world's first industrial cities, Manchester has a long history of the climatic effects of urbanism such as smog, and today aims to be a 'green' and 'sustainable' city (MacKillop, 2012). So it is apt that urban climate research is ongoing in the city. Manchester's UHI was mapped using ground and air transects in summer and found to be $\sim 3{ }^{\circ} \mathrm{C}$ during the day and up to $5{ }^{\circ} \mathrm{C}$ at night (Knight et al., 2010; Smith et al., 2011). Analysis using stationary monitors, found the UHI of Manchester to be as high as $8{ }^{\circ} \mathrm{C}$ in summer and $10^{\circ} \mathrm{C}$ in winter, with a higher probability of UHI occurrence in summer (Cheung, 2011).

A green roof within the University of Manchester campus, on the Precinct building, was chosen for the study. The roof was chosen because it has a conventional roof area $\left(900 \mathrm{~m}^{2}\right)$, consisting of concrete paving slabs, adjacent to a large $\left(408 \mathrm{~m}^{2}\right)$ intensive green roof, which is 30 years old. The area is 
classified as open midrise, characterised by a fairly open arrangement of buildings of 3-9 storeys with some trees, typical of an inner city university campus area (Stewart and Oke, 2012). All areas of the roof receive approximately the same amount of direct sunlight throughout the day until late evening when the paved area becomes shaded by adjacent buildings. The concrete paving slabs are not common components of Manchester's roof surfaces, which tend to be dominated by low albedo clay tiles on older Victorian buildings, or lightweight bituminous layers on modern flat-roofed building stock. Therefore, the temperature data gained from this roof are to be used in a comparative study against the adjacent green roof, and not to be used in generalisations about other low-albedo roofs.

The green roof has a soil layer $170 \mathrm{~mm}$ deep, which supports a wide variety of flora, including grasses, shrubs, rushes and small trees. The roof has, however, suffered from poor maintenance and some parts of the roof are dominated by invasive species such as Rubus fruticosa, Buddleja davidii and Plantago lanceolata. The green roof is L-shaped with two distinct sections as can be seen in Fig. 1. One area, G1, is dominated by patches of Juncus species and Aster novi-belgii. G2 is dominated by P. lanceolata, Senecio jacobaea, and the grasses, Agrostis stolonifera and Festuca rubra, and has a narrow path running through the middle made of the same paving slabs as the bare roof.

The green roof is of particular interest due to its age and the fact that the roof was not constructed specifically for the study. Green roof studies with an experimental component are often carried out on specially constructed roofs or prefabricated green roof panels, i.e. the green element was under the control of the investigator (Harazono et al., 1990; Takebayashi and Moriyama, 2007). It can be argued that studies of this type can over or underestimate the benefits of actual green roofs. Investigating a well established, real roof garden which is subject to local weather patterns, will reveal green roof characteristics that can be sensibly applied to the real world. It must be noted, however, that the study focuses on an intensive green roof, which cannot be supported by a lot of existing buildings without a structural refit at some cost to the building owner.

\subsection{Monitoring}

Temperature sensors (Tinytag 2PLUS TGP-4500) with an accuracy of $\pm 0.4{ }^{\circ} \mathrm{C}$ were housed $300 \mathrm{~mm}$ above the roof surface in Stephenson shields. Stands were painted white to reduce convective heat inputs into the shields above. Dry bulb temperature was recorded every 15 min synchronously between all sensors. All the sensors were initially checked for accuracy against each other by keeping in the same outdoor environment for a week and comparing with a Rotronics Hygroclip hand held monitor, which has an accuracy of $\pm 0.2^{\circ} \mathrm{C}$ and resolution of $0.004^{\circ} \mathrm{C}$. Monitoring commenced with one stand on the bare roof and one on the green roof area G1 (Fig. 1) on 05/06/2010. Two additional stands were added on 28/03/2011, with one placed on green roof area G2 and one placed as an additional monitor on the bare roof. Bare roof air temperatures were subsequently calculated as an average of the two monitors. The stands were placed centrally within the roof areas to avoid edge effects and minimise advection influences from adjacent surfaces. Advection effects are further minimised by the long-term monitoring approach and the open nature of the site. Sky View Factor is one for each stand, reflecting the open rooftop location.

Conclusions about the relationship between the air temperature above the roof and the sensible heat flux must be made carefully, due to the potential differences between the roof types. These arise from differences in flow over the roof surfaces and eddy interference within the green roof vegetation canopy. For the purpose of this comparative study, differences between the roofs are indicative of differences in the thermal impact of the roof surfaces on the overlying air mass. Flux differences, measurable by eddy covariance techniques, are assumed to be minimal, and air temperature is thus a suitable descriptor of thermal differences between roofs as found in other studies (Wong et al., 2003a; Getter et al., 2011).

Spot monitoring of surface temperatures was undertaken in the second and third summers of the study with a thermal imager (Fluke Ti25) on 27/07/2011 and 14/08/2012. Image analysis was carried out with Smartview software (Version 3.2). Similar weather conditions were sought as much as possible for these two comparison days, however, summer 2012 in the UK was characterised by a lot of rain and below average solar radiation due to persistent cloud, making the choice of day for spot monitoring difficult. Nonetheless, the two days were very similar in amount of solar radiation received and 


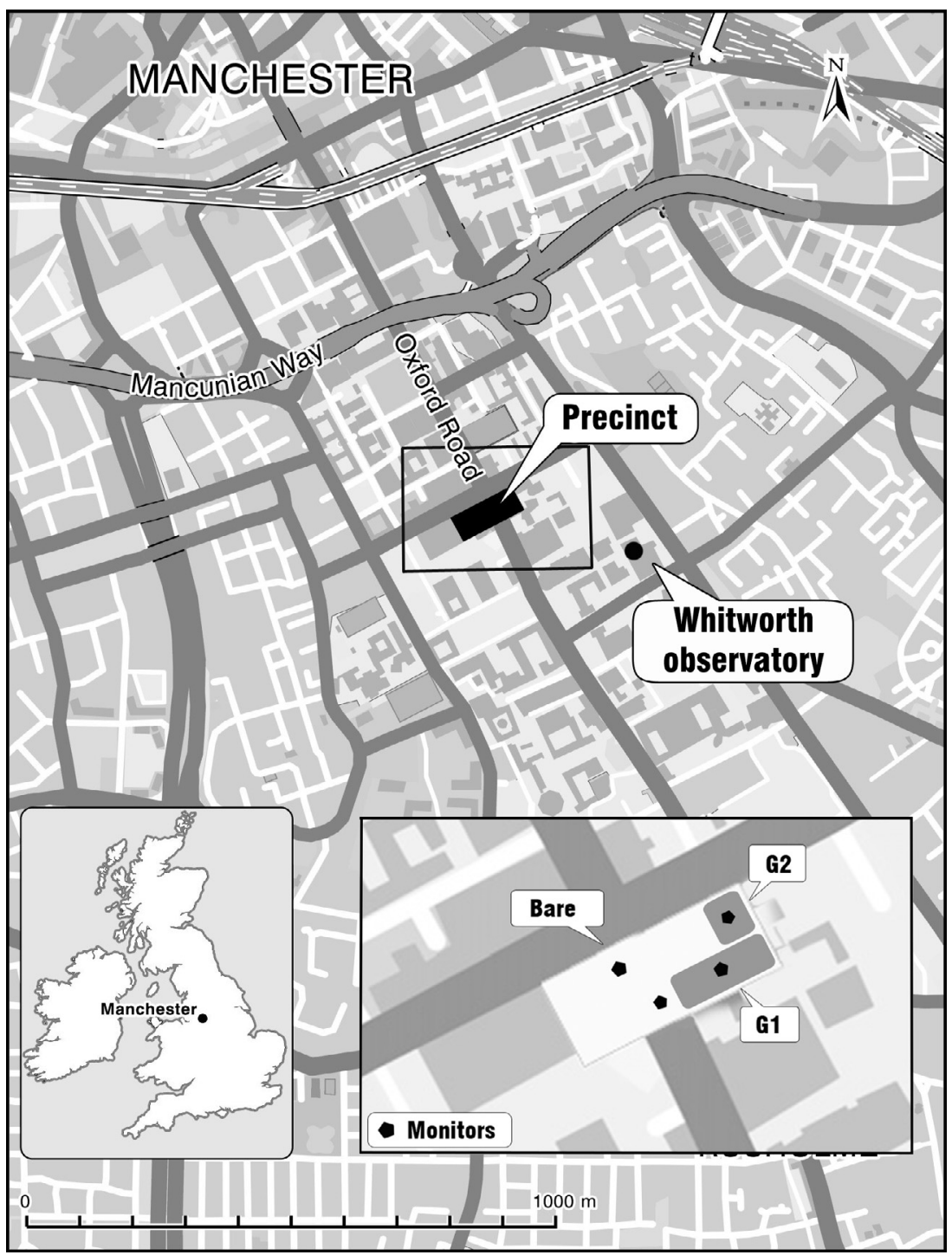

Fig. 1. Map to show the location of Precinct study site and the monitor locations on the roof.

humidity. Soil moisture conditions were fairly similar, with the 2011 monitoring occurring 5 days after rainfall $(3 \mathrm{~mm})$ and the 2012 occurring 7 days after significant rainfall $(4.3 \mathrm{~mm})$ but with a small shower $(1.2 \mathrm{~mm}) 2$ days previous. Peak daytime wind speeds in 2011 were $3.5 \mathrm{~m} \mathrm{~s}^{-1}$ compared with $5 \mathrm{~m} \mathrm{~s}^{-1}$ in 2012 which contributed to maximum temperatures of $25^{\circ} \mathrm{C}$ in 2011 compared with $23^{\circ} \mathrm{C}$ in 2012.

A septum tensiometer (Skye Instruments) situated between G1 and G2 logged data from November 2010. This was converted to soil moisture content using data from extensive soil characterisation experiments (carried out and personally communicated by C. Agnew, 15/08/2012). Meteorological data were available from the Whitworth Observatory (UOM, 2012), situated close to the Precinct roof (Fig. 1). 


\subsection{Data analysis}

Data were found to be not normal using the Anderson-Darling test, thus non-parametric data analysis was implemented. Monthly median temperatures were compared between the three roof areas, as were daily temperature cycles for the whole study period. Diurnal trends in the temperature differences between the two green roofs and the bare roof were also investigated. Data were organised by season for the latter analysis, defined as winter (Dec, Jan, Feb), spring (Mar, Apr, May), summer (Jun, Jul, Aug) and autumn (Sep, Oct, Nov). Spring 2011 consisted of fewer readings due to the new monitors only being placed on G2 and the bare roof in late March. Statistical analyses were carried out using $R$ (version 2.13.2) and SPSS (version 16 for Windows).

\section{Results}

\subsection{Vegetation dynamics}

A major characteristic of this study is that it was carried out on an existing, and aged, green roof compared experimentally to a bare roof. As a result, a number of elements related to the structure of the green roof were out of experimental control. Those of relevance to the study are the vegetation types and their dynamics. Near the start of the study, there was a prolonged dry period, during which G2 was intensively mowed, without irrigation, by the building owners. This severely damaged the green roof vegetation, which was predominantly grass, and resulted in large areas of substrate becoming uncovered. Over the next two growing seasons, this was gradually colonised by numerous windblown plant species and mosses. By summer 2012 G2 resembled a meadow, with some small bare patches remaining. G1 was not mowed because grass was not dominant here, however, over the three growing seasons of the study, G1 experienced a gradual spread of $A$. novi-belgii. This herbaceous perennial forms dense thickets of growth up to $120 \mathrm{~cm}$ tall. By summer 2012 the monitor on G1 was surrounded by this growth.

\subsection{Healthy green roof}

The Spearman Rank Order Correlation between recorded temperature values from each season was calculated. The temperatures are highly significantly correlated $(p<0.01)$ with $R$ values between 0.980 and 0.997 .

The air temperature distributions by month are shown in Fig. 2. The outliers represent the natural skewness of the monthly-averaged temperature data, which tends to be positive in warmer months. The median temperature is consistently lowest on G1, while the bare roof is most frequently the highest. The difference between the two is $0.43^{\circ} \mathrm{C}$ on average (data range of differences of $4.2^{\circ} \mathrm{C}$ cooler to $3.1^{\circ} \mathrm{C}$ warmer, S.D. $0.7^{\circ} \mathrm{C}$ ), with a minimum average monthly difference of $0.1^{\circ} \mathrm{C}$ in January 2012 and a maximum average monthly difference of $1.06{ }^{\circ} \mathrm{C}$ in August 2012. Differences are statistically significant for nine of the 17 months, using the Kruskal-Wallis test (Table 1). Post-hoc tests using MannWhitney test with Bonferroni correction showed significant differences exist primarily between G1 and Bare and secondly between G1 and G2. The magnitude of this cooling effect in comparison to the bare roof can be seen in Fig. 3. G1 is consistently cooler than the bare roof in every month. G2 displays similar trends, with a lessened cooling effect in winter months, and in April 2012 which was unseasonably cold. The cooling effect on G1 increases to a maximum at the end of the study.

Fig. 4 shows the daily cycle of the above-roof air temperatures averaged hourly for the whole period that all four monitoring stands were in place. G1 displays the lowest temperatures throughout the $24 \mathrm{~h}$ cycle, with a maximum difference from the bare roof between $21: 00$ and 22:00 of $1.18{ }^{\circ} \mathrm{C}$. However, the bare roof has slightly lower temperatures, differing only by $0.1{ }^{\circ} \mathrm{C}$, from $11: 00$ to $12: 00$. G2 displays the highest temperatures during the day, becoming cooler than the bare roof in the late evening.

The diurnal patterns of the temperature difference $(\delta T)$, calculated as green roof temperature minus bare roof temperature, can be seen in Fig. 5, organised by season. A broadly similar trend in all seasons 


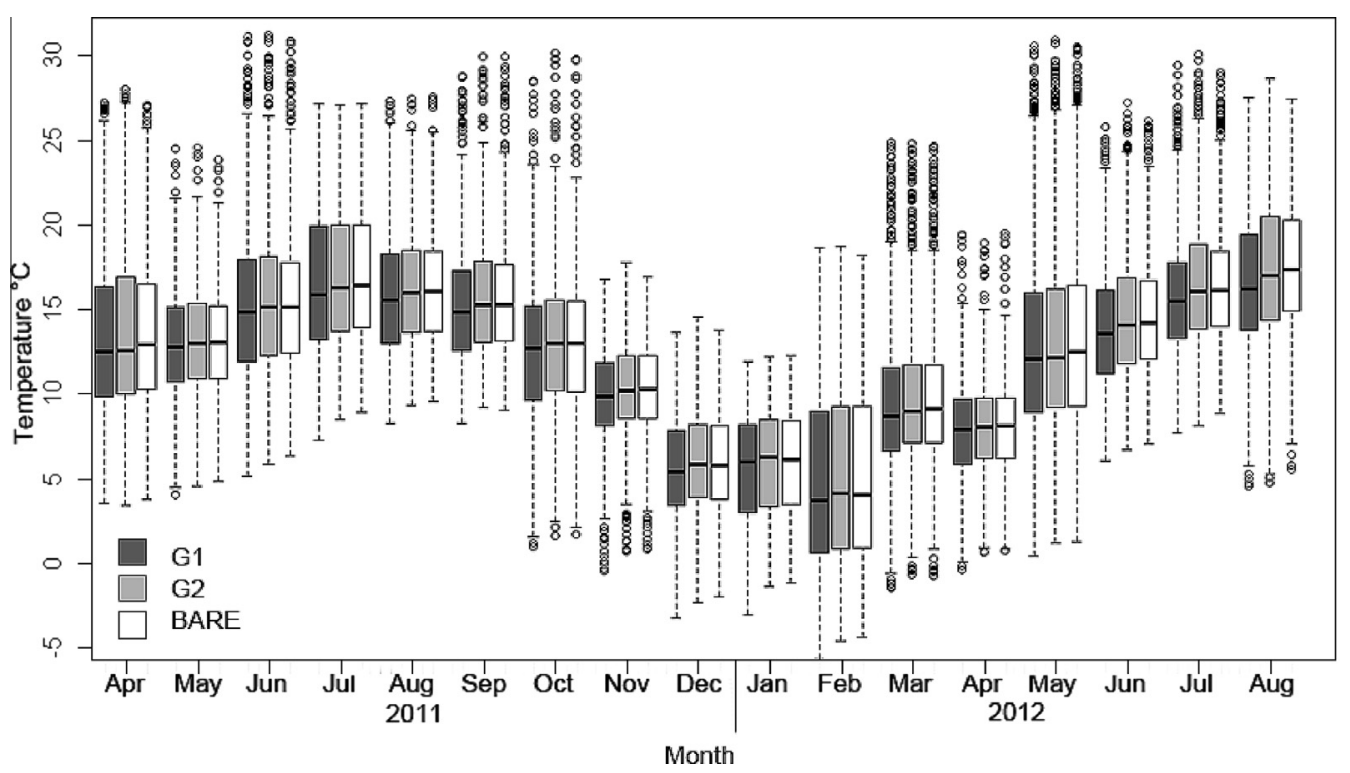

Fig. 2. Boxplots of the monthly air temperatures at $300 \mathrm{~mm}$ above the surface recorded on the three study roofs. G1 is the undamaged green roof, G2 the damaged green roof and BARE is the adjacent conventional roof surface.

Table 1

Kruskal-Wallis $\chi^{2}$ values.

\begin{tabular}{llllllllll}
\hline 2011 & Apr & May & Jun & Jul & Aug & Sep & Oct & Nov & Dec \\
\hline & 2.56 & 2.03 & 2.52 & $6.95^{*}$ & $9.1^{* *}$ & $9.15^{* *}$ & $6.4^{*}$ & $11.7^{* *}$ & $7.68^{*}$ \\
2012 & Jan & Feb & Mar & Apr & May & Jun & Jul & Aug & \\
\hline & 5.69 & 2.33 & 4.87 & 1.82 & 1.38 & $15.08^{* *}$ & $19.71^{* *}$ & $30.01^{* *}$ \\
\hline
\end{tabular}

* Significant at $p<0.05$.

** Significant at $p<0.01$.

can be seen throughout the study whereby the air above the green roofs is much cooler than over the bare roof at night, and either less cool, or warmer, during the day. This cycle has a larger amplitude in warmer seasons with a maximum cooling effect of $-1.58{ }^{\circ} \mathrm{C}$ seen on $\mathrm{G} 1$ at the 21:00 time period of summer 2012. The timing of this maximum cooling effect in the late evening is also seen on G2 in the summers of 2011 and 2012 and spring 2012. $\delta T$ values for G1 are more likely to become positive in warmer seasons, however the timings of the switch to positive values and when the peak positive value occurs vary. The larger amplitudes in summer start with large daytime positive $\delta T$ peaks in Summer 2010 but this becomes dampened in subsequent years, with $\mathrm{G} 1$ being cooler than the bare roof for a larger proportion of the time in summer 2012. The peak cooling effect of the green roofs tends to occur in the late evening at around $22: 00 \mathrm{~h}$, followed by a steady return of $\delta T$ towards zero until the rising sun starts the diurnal thermal budget cycle again.

The peak in positive $\delta T$ in the cycle occurs in late morning and tends to start moving back towards negative values after midday, however there is no consistent seasonal pattern to when this occurs. Temperatures above G1 are very similar to those above the bare roof during winter 2010/11 (winter 2010 in Fig. 5) and that winter was characterised by being exceptionally cold for the UK, with prolonged sub-zero temperatures in December 2010. $\delta T$ values in winter 2011/12 are quite erratic, and also do not stray far from zero. Less solar forcing and persistent damp conditions in temperate winters would explain the lack of temperature differences between the green and bare roofs. 


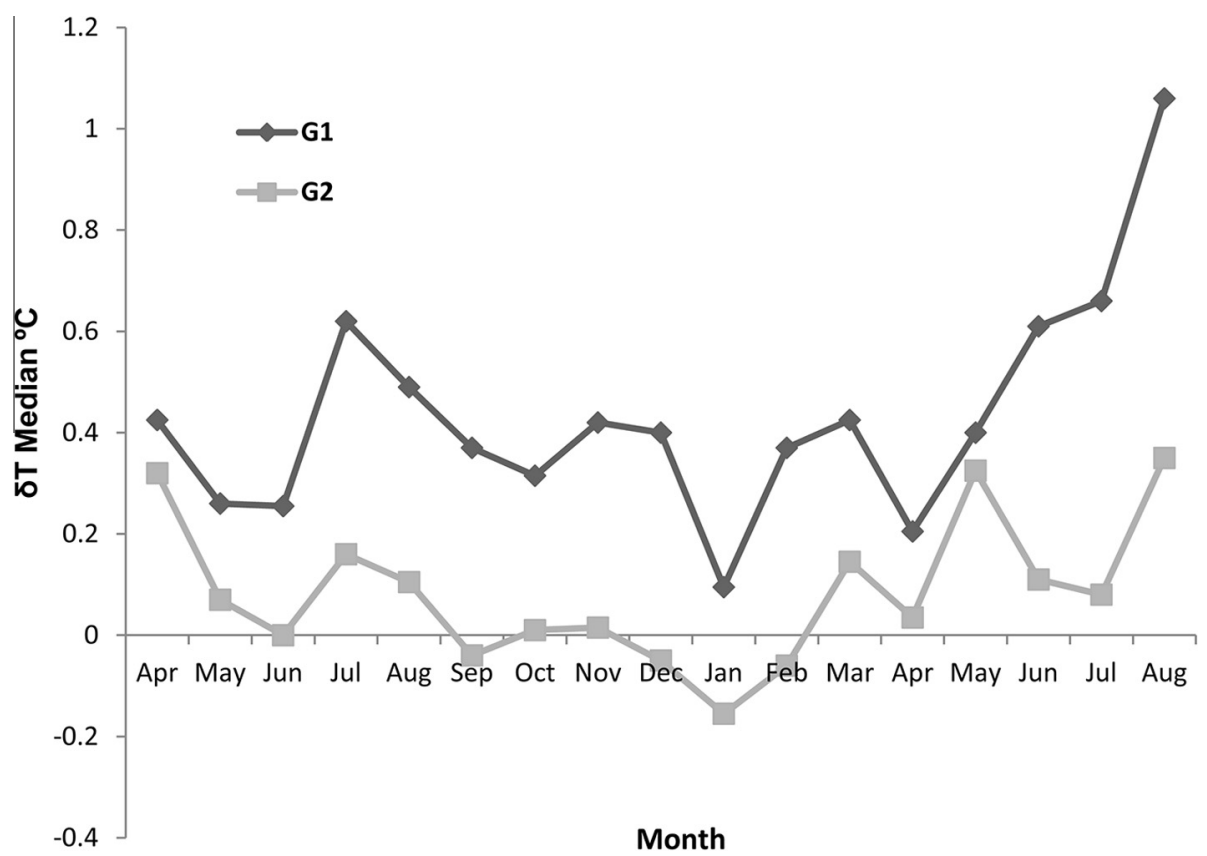

Fig. 3. Temperature difference $(\delta T)$ of the monthly medians ( $\mathrm{G} 1=$ bare roof-G1, $\mathrm{G} 2$ = bare roof-G2).

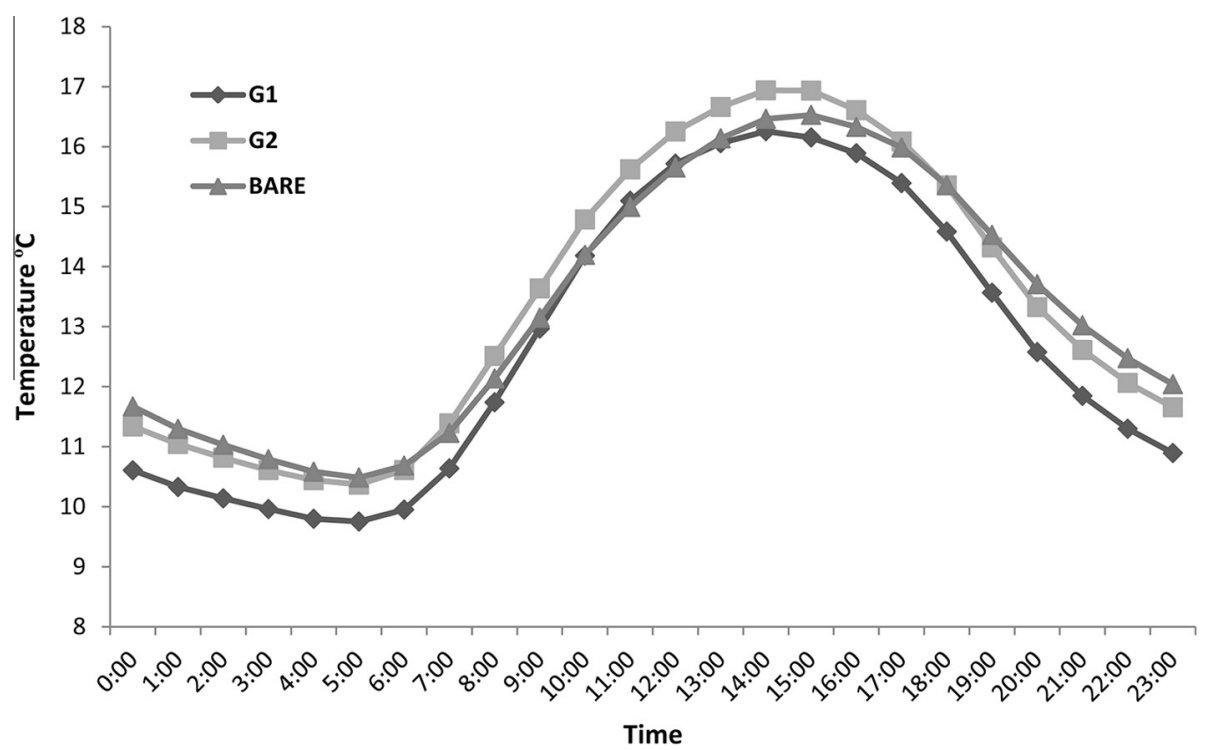

Fig. 4. Average hourly temperatures for the period $28 / 03 / 2011$ to $31 / 08 / 2012$.

Spring 2011 was unusually warm and dry, with an absence of rain from 11/04/2011 until 05/05/ 2011. The tensiometer on the green roof registered soil water content falling steadily from the usual $10-3.5 \%$ vol. 

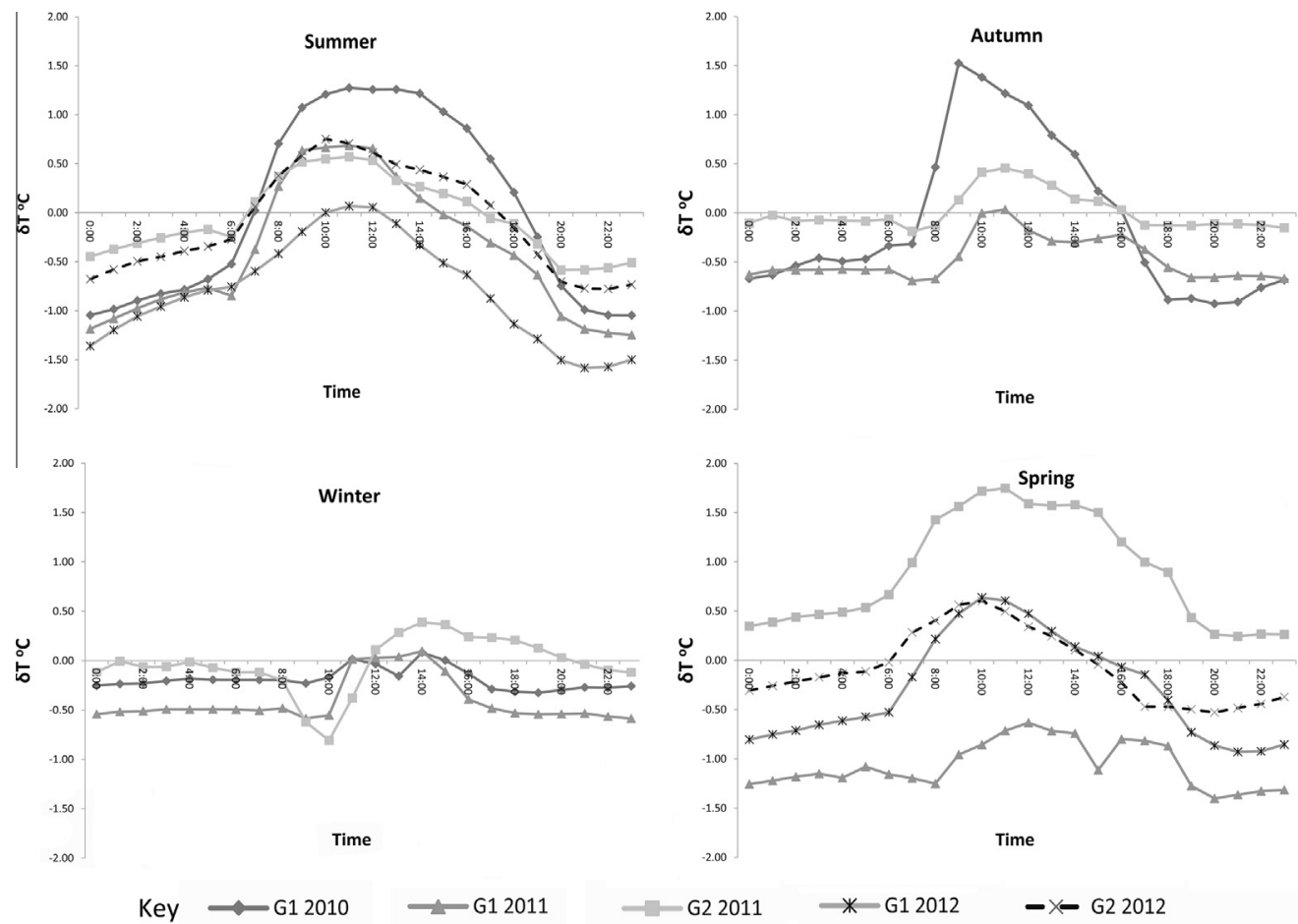

Fig. 5. Diurnal trends of the temperature difference $(\delta T)$ between the green roof areas and the conventional roof area for each season.

The upper percentiles of air temperature for each season were calculated to identify the warmest days in each period. Of the days identified there were two separate occasions with three consecutive warm days (over the 99th percentile) that could warrant particular attention. These were 20-22/04/2011 and 28-30/09/2011. Temperature profiles of these periods plus a day either side can be seen in Figs. 6 and 7. The general trend is upheld, with the green roof areas being cooler at night and warmer during the day with the exception of autumn 2011, where G1 also remains cooler during most of the day, except for a brief high in the late mornings.

Fig. 8 shows the differences in surface temperature between the bare roof and G1 with a difference in the mean of the selected areas of $18.5^{\circ} \mathrm{C}$. Surface temperatures were also lower on $\mathrm{G} 2$ than the path that runs through it (Figs. 9 and 10).

\subsection{Damaged green roof}

The monthly median temperatures above G2 were not significantly different from those over the bare roof, with the Kruskal-Wallis test (data range of differences of $2.9^{\circ} \mathrm{C}$ cooler to $8.3^{\circ} \mathrm{C}$ warmer, S.D. $0.56^{\circ} \mathrm{C}$ ). Temperatures were actually highest of all three roofs over this damaged section of roof from 07:00 to 15:00 in the average hourly temperature data (Fig. 4), reaching a maximum average difference over the bare roof of $0.63{ }^{\circ} \mathrm{C}$ at $11: 00$. Temperature profiles from the 99th percentile events (Figs. 6 and 7) also display this daytime warm air temperature maximum over G2. The temperature becomes cooler than over the bare roof by late evening, however the cooling effect is not as pronounced as with G1. The maximum difference in Fig. 4 is only $0.41{ }^{\circ} \mathrm{C}$, between $21: 00$ and 23:00, compared to $1.18^{\circ} \mathrm{C}$ for $\mathrm{G} 1$.

Spring 2011 was the first season that a monitor was deployed on G2 and it is also when the roof was in its worst state of damage. $\delta T$ values for this season display a similar cycle to other seasons with 


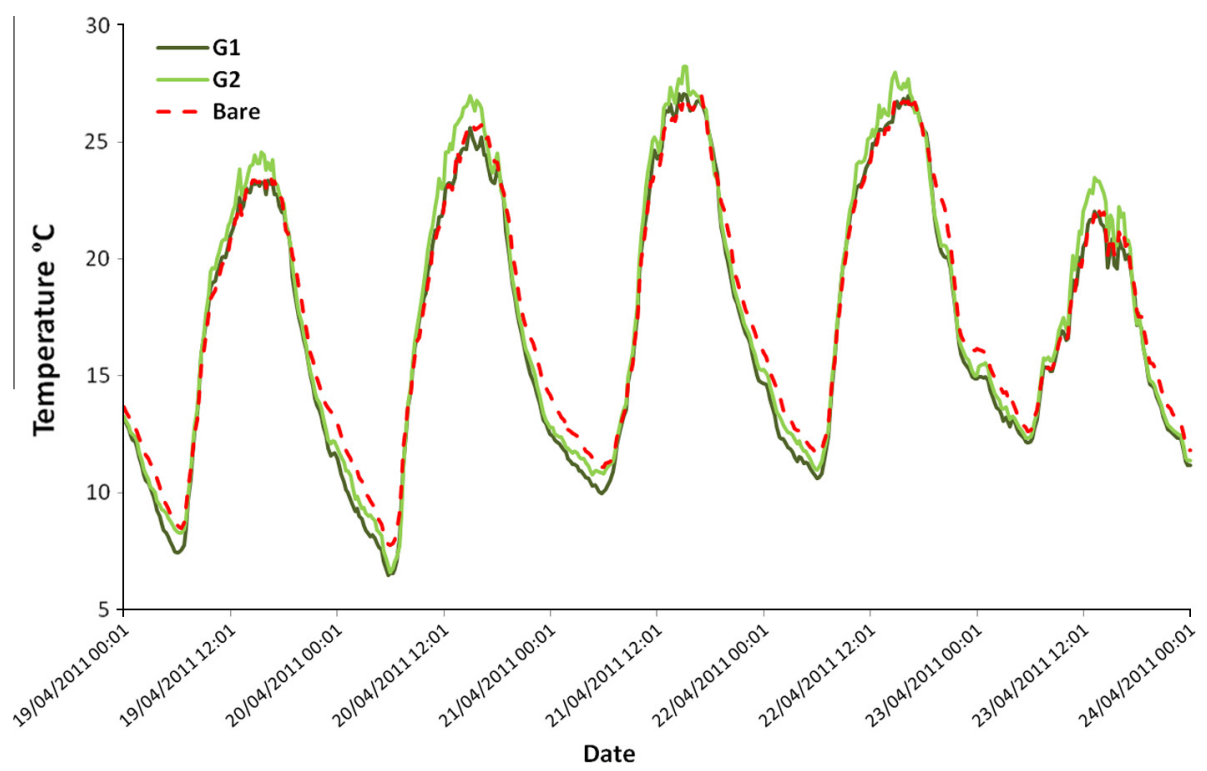

Fig. 6. Temperature profile for the three roof areas during one of the 3-day 95th percentile exceedance periods (20-22 April 2011, with a day either side).

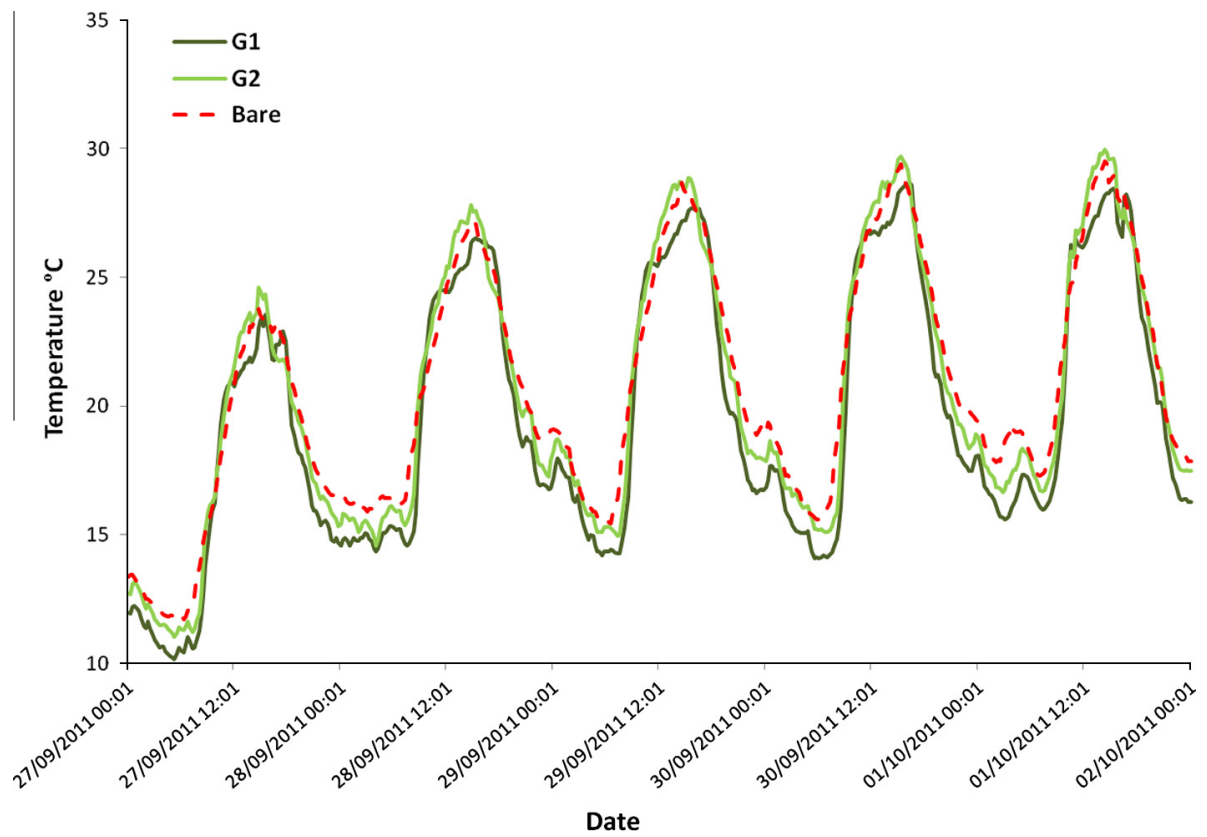

Fig. 7. Temperature profile for the three roof areas during one of the 3-day 95th percentile exceedance periods (28-30 September 2011, with a day either side).

a cooling effect at night and warmer air temperatures during the day (Fig. 4). For every season $\delta T$ values are consistently positive during the day reaching a peak before midday of around $0.5^{\circ} \mathrm{C}$. In summer 2012 , the peak reached $0.75^{\circ} \mathrm{C}$ and $\delta T$ values were positive for approximately half of the $24 \mathrm{~h}$ 

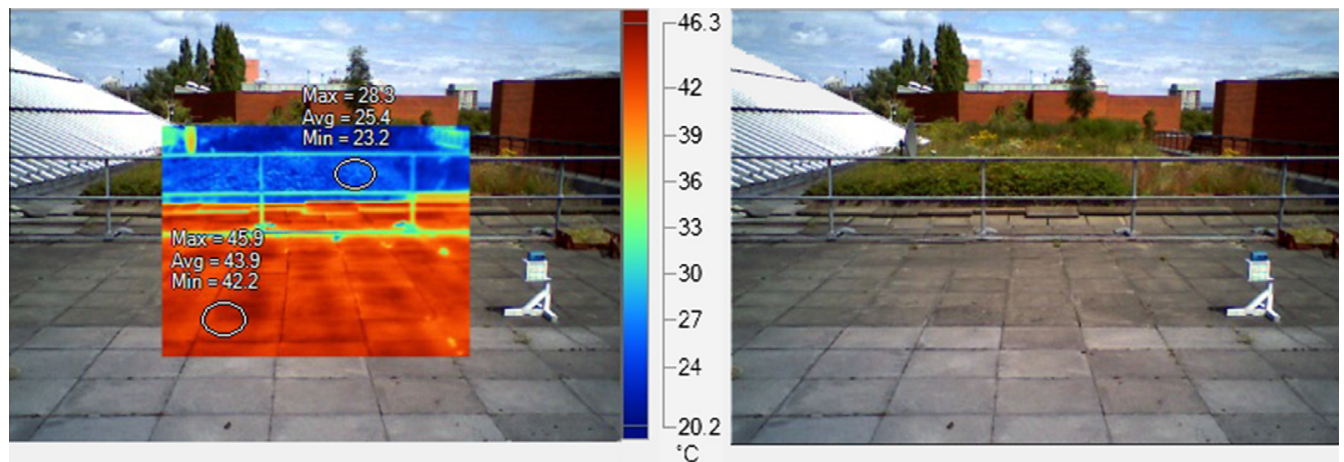

Fig. 8. Thermal image of the bare roof, with green roof area G1 behind, taken at 14:00 on 26/07/2011. Image is inclusive of any reflected radiation incurred by non-perpendicular angle of photograph. (For interpretation of the references to colour in this figure legend, the reader is referred to the web version of this article.)
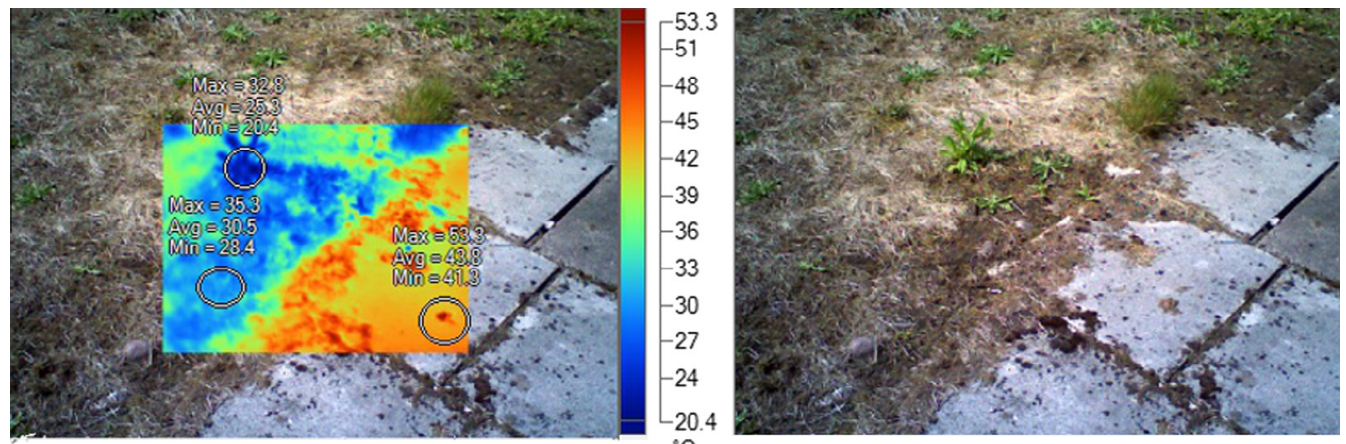

${ }^{\circ} \mathrm{C}$

Fig. 9. Thermal image of G2 and concrete slab path taken at 14:00 on 26/07/2011.
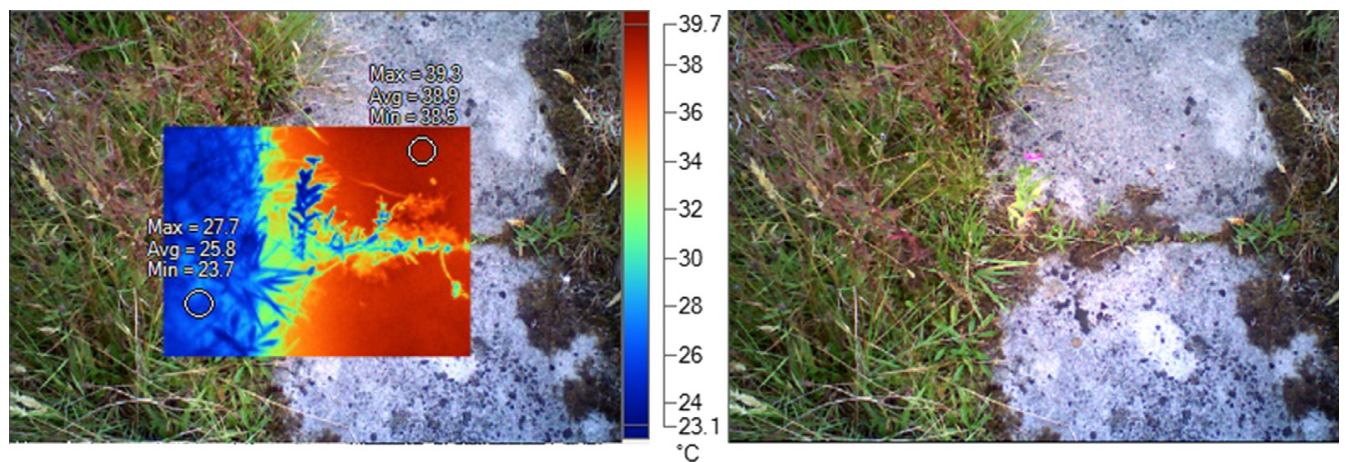

Fig. 10. Thermal image of G2 and concrete slab path taken at 14:00 on 14/08/2012.

cycle. $\delta T$ values throughout the whole study are only negative for $61.8 \%$ of the time, compared to $80 \%$ for G1. Peak night time cooling over G2 barely exceeded half a degree, apart from an anomalous dip in the $\delta T$ values in winter $2011 / 12$ and in summer 2012 when an average peak cooling of $-0.78{ }^{\circ} \mathrm{C}$ was recorded at 22:00. 
Surface temperatures on the damaged grass in Fig. 9 were on average $13.3^{\circ} \mathrm{C}(70 \%)$ lower than those on the paved path. The grass was $13.1^{\circ} \mathrm{C}(67 \%)$ cooler than the path in 2012 (Fig. 10), which was not as warm as the path in the 2011 image. The selected area over the living individual of $P$. lanceolata in Fig. 9 shows average temperatures $18.5^{\circ} \mathrm{C}(58 \%)$ cooler than the paving, with a similar surface temperature of just over $25^{\circ} \mathrm{C}$ to the grass in 2012 .

\section{Discussion}

\subsection{Localised cooling effect}

Cooler air was found over both green roof sections when compared to the adjacent bare roof. This effect was more pronounced for G1 and the difference in the monthly median values was often significant. This localised cooling, of up to $1.06{ }^{\circ} \mathrm{C}$ difference in the monthly median, (and $4.2{ }^{\circ} \mathrm{C}$ maximum of the range) is a notable influence of green roof vegetation on the internal boundary-layer (IBL) that occurs when air passes from one type of surface over another (Erell et al., 2011). This is comparable to the $0.94{ }^{\circ} \mathrm{C}$ cooler temperatures found in parks in the meta-analysis by Bowler et al. (2010), although their figure is for daytime cooling.

The largest cooling effect tended to occur in the late evening, with maximum negative average $\delta T$ values between 21:00 and 22:00. This can be explained as the time when long wave radiation of thermal energy accumulated in the bare roof during the day (Meyn and Oke, 2009) would be at its greatest relative to the green roofs, rather than an increase in latent cooling on the green roofs at this specific time. The long wave radiation would cause a corresponding rise in the sensible heat of the overlying air mass, especially in periods of stable atmospheric conditions. One way of looking at the effects of urban vegetation is that it warms the environment less, rather than cools more (Dimoudi and Nikolopoulou, 2003). Wong et al. (2003a) also found the timing of significant cooling of the air at $300 \mathrm{~mm}$ above a tropical, intensive green roof was from sunset to sunrise, with a maximum difference of $4.2^{\circ} \mathrm{C}$ at the start of this period.

As the study takes place on a rooftop there will be no canyon effects on nocturnal cooling, thus the thermal properties of the surfaces become more important for the differences seen between roofs (Erell et al., 2011). Evaporative fluxes are weak at night so the green roofs must have cooled soon after sunset in order to explain the difference between them and the bare roof, which will be slowly releasing stored energy.

Conversely $\delta T$ values were at a minimum during the daytime and often moving into positive values, indicating warmer air over the green roofs. The timing of this peak positive $\delta T$ tended to be in the late morning to midday. This could be due to differences in the thermal capacity of the surfaces, with the bare roof taking longer to warm up than the relatively thin soil substrate and plant biomass on the green roofs (Wong et al., 2007). Uncovered substrate could also be adding to these daytime higher temperatures and this will be discussed further in Section "Effects of green roof damage".

The predicted pattern is for cooling in the daytime when plant stomata are open and evapotranspiration rates are high, thus creating an increase in latent heat fluxes and a consequent decrease in sensible heat. Previous studies that focussed on surface temperatures found daytime cooling on green roofs (Liu and Baskaran, 2003; Türkeri et al., 2010) and the assumption is that this will translate into cooler air temperatures. Surface temperatures, on the warm sunny days chosen for spot monitoring, were lower in this study yet air temperatures were not lower. A study on tropical green roofs found both daytime and night time cooling of overlying air, with maximum day temperatures $1.7^{\circ} \mathrm{C}$ below the control and minimum night temperatures $0.9{ }^{\circ} \mathrm{C}$ below the control for a grass roof at $200 \mathrm{~mm}$ above the surface (Jim, 2012).

A lack of predicted day time cooling on the green roofs can be hard to explain. Vegetated surfaces can be quite complex in their thermal behaviour due to lower wind speeds caused by friction from the plant biomass, more water available for evapotranspiration, and plant canopy interactions with both incoming solar and outgoing long wave radiation (Erell et al., 2011). Jim (2012) found the $700 \mathrm{~mm}$ high canopy of an intensive shrub roof actually trapped air, which acts as a heat sink giving heat accumulations at around $600 \mathrm{~mm}$. Similar trapping of air could explain a diminished cooling effect on G1 
during the day, however this would only apply in summer and autumn when the perennial A. novi-belgii is in full growth.

\subsection{Effects of green roof damage}

Median monthly air temperatures on G2 did not differ statistically from those on the bare roof. This is highly likely due to the fact that the grass was damaged by drought and mismanagement. A cooling effect was apparent in the evenings, however, the cooling effect of G2 was lower than that of G1 while following roughly the same pattern (Fig. 3). The cooling effect appeared to become stronger toward the end of the study when plant cover was increasing. The high cooling effect seen in April 2011 is unusual, however, as the roof was quite damaged at this point. That month was characterised by a prolonged period of unusually warm weather, with UK average temperatures being $3.7^{\circ} \mathrm{C}$ over the 1971-2000 average (Met Office, 2011). This may have greatly raised air temperatures above the bare roof, masking the warming experienced on G2. Cooling by evaporation from the soil is unlikely as the tensiometer data indicate quite severe water loss during this dry period.

Wong et al. (2007) found extensive green roof systems to be ineffective at reducing ambient air temperature during the day. This was due to poor vegetation coverage on the newly constructed roofs, which revealed large areas of dark substrate that subsequently displayed surface temperatures $4-5{ }^{\circ} \mathrm{C}$ warmer than the roof surface before the roof garden was installed. They concluded that the high surface temperatures of the substrate may have been responsible for ambient air temperatures measured above vegetated areas being higher than those measured above exposed surface. Higher surface temperatures were not seen on G2 at the spot monitoring events. Thus, while dark soil and its relatively low thermal capacity may be responsible for some heating of the air, some other process may be contributing to the higher temperatures seen. There is a concrete path that runs through G2, which could be adding sensible heat to the local air mass, however, it is only a narrow path taking up $9 \%$ of the area of G2, and can by no means account for the air temperatures over G2 being similar to, if not higher than, over the bare roof. The vegetation types that colonised G2 may have different cooling abilities than the types on G1. A previous study found some species displayed differences in their effect on the air temperature at $300 \mathrm{~mm}$, however, differences were only noticeable in the afternoon of days with high extreme temperature conditions (Blanusa et al., 2010). Structural differences certainly exist, with A. novi-belgii forming dense thickets on G1 and S. jacobaea growing more sparsely on G2 with areas of moss and exposed substrate in between. Some species are common to both roofs however - such as the grasses A. stolonifera and F. rubra.

The daily cycles in Fig. 5 show that the maximum positive $\delta T$ values for G2 were in the late morning. As with G1 this could be due to the bare roof taking longer to heat up than the thin soil substrates. On G2 the process tends to start sooner, reach higher maxima, and move back into negative values later than with G1. The maximum value reached in the seasonal averages is $0.81{ }^{\circ} \mathrm{C}$ in spring 2011 . As the vegetation grows back, and the substrate becomes more shaded, one would expect this daytime warming to diminish but a fairly high value of $0.75{ }^{\circ} \mathrm{C}$ was reached at the end of the study in summer 2012. An increase in evapotranspirative cooling from the greater plant biomass also apparently fails to result in the temperature profile of the air above G2 become more similar to G1.

Night time cooling was not as strong for G2 as with G1. Maximum cooling was reached in summer 2012 with $-0.78^{\circ} \mathrm{C}$. Higher temperatures were reached during the day in summer 2012 but cooler temperatures at night. Average $\delta T$ minimum of $-0.81^{\circ} \mathrm{C}$ was reached in winter $2011 / 12$, however this was more likely due to relative warming of the bare roof, which came earlier than in the previous year, in this season. Vegetation could be delaying daytime warming when the blanketing effect of snow and frost is not present in the mild winter of 2011/12.

\subsection{Local climate modification}

The intensive green roofs in this study were able to reduce the local air temperature when compared to an adjacent conventional roof. This may indicate a reduced convective sensible heat flux from the rooftop environment to the urban boundary layer which would translate into a lowered UHI effect. The cooling effect was at a maximum in the night time when the UHI effect is at its strongest so green 
roofs can help to improve the thermal comfort of cities, especially at night. A question to be asked, however, is how much spatial influence can individual green roofs have? The effect of the size of vegetated areas sufficient to produce a measurable effect is of great interest to planners (Erell et al., 2011). Green roofs exert a very local effect on the climate and can be seen as separate islands. Roof greening on a larger scale would potentially have a larger impact than isolated separate roofs by providing an effect greater than the sum of its parts. Research on grass plots and trees suggests that many small plots will be more effective than fewer large ones (Armson et al., 2012). A $1{ }^{\circ} \mathrm{C}$ lowering of air temperatures above the roof could magnify up to quite significant UHI impacts. Cooling of $0.8^{\circ} \mathrm{C}$ was proposed in a modelling study by Dimoudi and Nikolopoulou (2003) from just a $10 \%$ increase in the ratio of green to built urban surfaces.

The zone of influence of green roofs on ambient air temperature, and how that can be scaled up to the city level in modelling studies, is an important factor for future studies to determine. Vertical influences can be quite pronounced, with the air at $100 \mathrm{~cm}$ over a gravel roof found to be warmer than above a green roof (Getter et al., 2011). Cooling effects do become less marked with height, however, and no significant influence of green roofs was found at $160 \mathrm{~cm}$ above the surface (Jim and Peng, 2012). Winds affect the horizontal component of a green roof's influence, with cooler air being found at the leeward edge (Dimoudi and Nikolopoulou, 2003). Green roofs in large enough numbers could potentially improve the thermal comfort of pedestrians at street level (Gomez et al., 2008) by cumulative cooling impacts on the urban air mass.

An important point that this study has shown, is that urban green roofs, if they are to have the desired effect, need to be carefully managed. The cooling properties of the green roof can be quite severely impaired when the vegetation is damaged and bare substrate dominates. Therefore, irrigation in dry periods may be necessary and maintenance workers need to be made aware of the correct time to cut back vegetation. The FLL green roof guidelines recommend that contractual maintenance arrangements are made, with an extensive list of tasks to be considered for intensive roofs, such as watering, mulching and pruning 8-10 times a year (FLLp, 2008). Lawn roofs need extra attention, including mowing, aerating and repeat seeding 2-12 times a year. If more than $5 \%$ of the plant coverage has failed then replacements are needed (GRO, 2011). Additionally, the intensive green roofs in this study are not common due to the additional installation and maintenance costs associated with them. Extensive roofs, which are much more widespread, may have less of a cooling effect on the overlying air mass due to lower evapotranspirative cooling from the thinner substrate and reduced plant biomass.

Climate change predictions, such as summer rainfall decreases and more frequent heatwaves, will put severe drought stress on urban vegetation. If green infrastructure is to be used as climate change adaptation then it needs to be coupled with sensible installation and maintenance plans, for instance storage of rainwater in wetter months for irrigation in drier months.

\section{Conclusions}

- An intensive green roof, dominated by perennial shrubs, was able to lower the monthly median overlying air temperature at $300 \mathrm{~mm}$ by up to $1.06{ }^{\circ} \mathrm{C}$ when compared to an adjacent conventional paved roof.

- The cooling effect was strongest at night with an average difference of $1.58^{\circ} \mathrm{C}$.

- Some daytime warming was observed on the green roofs with a peak difference relative to the bare roof in late mornings. Differences in the thermal capacity of the roof materials and vertical mixing characteristics could explain this.

- A combination of drought and mismanagement caused severe damage to the vegetation on one of the green roofs. The cooling effect was impaired on this roof with daytime air temperatures being higher than over the bare roof for a larger proportion of the day than over the other, undamaged, green roof. Cooling still occurred at night, however, although with a lower maximum average relative cooling of $0.78{ }^{\circ} \mathrm{C}$ observed. 


\section{Acknowledgements}

This work was funded by NERC with CASE contributions from Manchester City Council. The use of the IR camera was provided by Andrew Pinkerton, from the School of Mechanical, Aerospace and Civil Engineering at the University of Manchester. Advice and assistance was gratefully received from John Moore and Clive Agnew at the University of Manchester. The botanical survey of the roof was carried out by Cameron Crook.

\section{References}

Akbari, H., Konopacki, S., 2005. Calculating energy-saving potentials of heat-island reduction strategies. Energy Policy 33, $721-$ 756.

Akbari, H., Menon, S., Rosenfeld, A., 2009. Global cooling: increasing world-wide urban albedos to offset $\mathrm{CO}_{2}$. Climatic $\mathrm{Change}$ $94,275-286$.

Alexandri, E., Jones, P., 2007. Developing a one-dimensional heat and mass transfer algorithm for describing the effect of green roofs on the built environment: comparison with experimental results. Building and Environment 42, 2835-2849.

Armson, D., Stringer, P., Ennos, A.R., 2012. The effect of tree shade and grass on surface and globe temperatures in an urban area. Urban Forestry \& Urban Greening 11, 245-255.

Armstrong, B.G., Chalabi, Z., Fenn, B., Hajat, S., Kovats, S., Milojevic, A., Wilkinson, P., 2011. Association of mortality with high temperatures in a temperate climate: England and Wales. Journal of Epidemiology and Community Health 65, 340-345.

Barrio, E.P.D., 1998. Analysis of the green roofs cooling potential in buildings. Energy and Buildings 27, 179-193.

Blanusa, T., Vaz monteiro, M., Cameron, R.W.F., 2010. Alternatives to Sedum on Green Roofs? Utilising Plants' Cooling Potential. Paper presented at the World Green Roof Congress, London, 2010.

Bowler, D.E., Buyung-Ali, L., Knight, T.M., Pullin, A.S., 2010. Urban greening to cool towns and cities: a systematic review of the empirical evidence. Landscape and Urban Planning 97, 147-155.

Castleton, H.F., Stovin, V., Beck, S.B.M., Davison, J.B., 2010. Green roofs; building energy savings and the potential for retrofit. Energy and Buildings 42, 1582-1591.

Cavan, G., 2010. Climate change projections for greater Manchester. In: U.O.M. (Ed.), Ecocities Project, Manchester, UK.

Cheung, H.K.W., 2011. An urban heat island study for building and urban design, Ph. D Thesis, The University of Manchester.

Dimoudi, A., Nikolopoulou, M., 2003. Vegetation in the urban environment: microclimatic analysis and benefits. Energy and Buildings 35, 69-76.

Donaldson, G.C., Kovats, R.S., Keatinge, W.R., Mcmichael, R.J., 2001. Heat- and cold-related mortality and morbidity and climate change. In: Maynard, R.L. (Ed.), Health Effects of Climate Change in the UK. Department of Health, London.

Erell, E., Pearlmutter, D., Williamson, T., 2011. Urban Microclimate: Designing the Spaces Between Buildings. Earthscan Ltd., London, Chapter 9 - Vegetation.

FLL, 2008. Forschungsgesellschaft Landschaftsentwicklung Landschaftsbau e. V. (FLL) Guidelines for the Planning, Construction and Maintenance of Green Roofing, English language edition, available at www.fll.de (Ed.) FLL, Bonn.

Getter, K.L., Rowe, D.B., Andresen, J.A., Wichman, I.S., 2011. Seasonal heat flux properties of an extensive green roof in a Midwestern US climate. Energy and Buildings 43, 3548-3557.

Gill, S.E., Handley, J.F., Ennos, A.R., Pauleit, S., 2007. Adapting cities for climate change: the role of the green infrastructure. Building and Environment 33, 115-133.

Gomez, F., Montero, L., de Vicente, V., Sequi, A., Castilla, N., 2008. Vegetation influences on the human thermal comfort in outdoor spaces: criteria for urban planning. In: Gospodini, A., Brebbia, C.A. (Eds.), 5th International Conference on Urban Regeneration and Sustainability (The Sustainable City). Wit Press/Computational Mechanics Publications, Skiathos, Greece, pp. 151-163.

Grant, G., Luke Engleback, Barry Nicholson., 2003. Green roofs: their existing status and potential for conserving biodiversity in urban areas. In: Produced for English Nature by EcoSchemes, Ltd. (Ed.), English Nature Research, Report No. 498.

GRO, 2011. The GRO Green Roof Code - Green Roof Code of Best Practice for the UK 2011, Groundwork Sheffield.

Gupta, R., Gregg, M., 2012. Using UK climate change projections to adapt existing English homes for a warming climate. Building and Environment 55, 20-42.

Hall, J.M., Handley, J.F., Ennos, A.R., 2012. The potential of tree planting to climate-proof high density residential areas in Manchester, UK. Landscape and Urban Planning 104, 410-417.

Harazono, Y., Teraoka, S., Nakase, I., Ikeda, H., 1990. Effects of rooftop vegetation using artificial substrates on the urban climate and the thermal load of buildings. Energy and Buildings 15, 435-442.

Jim, C., 2012. Effect of vegetation biomass structure on thermal performance of tropical green roof. Landscape and Ecological Engineering 8, 173-187.

Jim, C.Y., Peng, L.L.H., 2012. Weather effect on thermal and energy performance of an extensive tropical green roof. Urban Forestry \& Urban Greening 11, 73-85.

Knight, S., Smith, C., Roberts, M., 2010. Mapping Manchester's urban heat island. Weather 65, 188-193.

Köhler, M., Schmidt, M., Laar, M., 2003. Green Roofs as a Contribution to Reduce Urban Heat Islands. RIO 3 - World Climate \& Energy Event, Rio de Janeiro, Brazil.

Landsberg, H., 1981. The Urban Climate. Academic Press, NY.

Larsen, J., 2003. Record Heatwave in Europe takes 35,000 lives. Earth Policy Institute.

Larsen, J., 2006. Setting the record straight: more than 52000 Europeans died from heat in summer 2003, Earth Policy Institute, 2006 [online]. Available from: <http://www.earth-policy.org/Updates/2006/Update56.htm> [accessed]. 
Lindley, S.J., Handley, J.F., Theuray, N., Peet, E., Mcevoy, D., 2004. Adaptation strategies for climate change in the urban environment: assessing climate change related risk in UK urban areas. In: 13th Annual SRA-Europe Conference. Routledge Journals, Taylor \& Francis Ltd., Paris, France, pp. 543-568.

Liu, K., Baskaran, B., 2003. Thermal performance of green roofs through field evaluation. In: Proc. of 1st North American Green Roof Conference: Greening Rooftops for Sustainable Communities, 2003, Chicago. The Cardinal Group, Toronto, pp. 273282.

Mackillop, F., 2012. Climatic city: two centuries of urban planning and climate science in Manchester (UK) and its region. Cities 29, 244-251.

Macmillan, G., 2004. York University Rooftop Garden Stormwater Quantity and Quality Performance Monitoring Report. Greening Rooftops for Sustainable Communities, Portland.

MCC, 2010. Manchester's Population Historically [online]. Available: <http://www.manchester.gov.uk/downloads/download/ 4220/corporate_research_and_intelligence_population_publications $>$ [accessed January 2012].

MET Office, 2011. <http://www.metoffice.gov.uk/climate/uk/2011/april.html> [online], [accessed].

Meyn, S.K., Oke, T.R., 2009. Heat fluxes through roofs and their relevance to estimates of urban heat storage. Energy and Buildings 41, 745-752.

Murphy, J.M., Sexton, D.M.H., Jenkins, G.J., Boorman, P.M., Booth, B.B.B., Brown, C.C., Clark, R.T., Collins, M., Harris, G.R., Kendon, E.J., Betts, R.A., Brown, S.J., Howard, T.P., Humphrey, K.A., Mccarthy, M.P., Mcdonald, R.E., Stephens, A., Wallace, C., Warren, R., Wilby, R., Wood, R.A., 2009. UK Climate Projections. Science Report: Climate Change Projections, Met Office Hadley Centre, Exeter, UK, p. 192.

Niachou, A., Papakonstantinou, K., Santamouris, M., Tsangrassoulis, A., Mihalakakou, G., 2001. Analysis of the green roof thermal properties and investigation of its energy performance. Energy and Buildings 33, 719-729.

Oke, T.R., 1982. The energetic basis of the urban heat-island. Quarterly Journal of the Royal Meteorological Society 108, 1-24.

Robine, J.-M., Cheung, S.L.K., le Roy, S., van Oyen, H., Griffiths, C., Michel, J.-P., Herrmann, F.R., 2008. Death toll exceeded 70,000 in Europe during the summer of 2003. Comptes Rendus Biologies 331, 171-178.

Sailor, D.J., 2008. A green roof model for building energy simulation programs. Energy and Buildings 40, 1466-1478.

Sfakianaki, A., Pagalou, E., Pavlou, K., Santamouris, M., Assimakopoulos, M.N., 2009. Theoretical and experimental analysis of the thermal behaviour of a green roof system installed in two residential buildings in Athens, Greece. International Journal of Energy Research 33, 1059-1069.

Smith, C., Lawson, N., 2012. Identifying extreme event climate thresholds for greater Manchester, UK: examining the past to prepare for the future. Meteorological Applications 19, 26-35.

Smith, C., Lindley, S., Levermore, G., 2009. Estimating spatial and temporal patterns of urban anthropogenic heat fluxes for UK cities: the case of Manchester. Theoretical and Applied Climatology 98, 19-35.

Smith, C.L., Webb, A., Levermore, G.J., Lindley, S.J., Beswick, K., 2011. Fine-scale spatial temperature patterns across a UK conurbation. Climatic Change 109, 269-286.

Solecki, W.D., Rosenzweig, C., Parshall, L., Pope, G., Clark, M., Cox, J., Wiencke, M., 2005. Mitigation of the heat island effect in urban New Jersey. Global Environmental Change Part B: Environmental Hazards 6, 39-49.

Speak, A.F., Rothwell, J.J., Lindley, S.J., Smith, C.L., 2012. Urban particulate pollution reduction by four species of green roof vegetation in a UK city. Atmospheric Environment 61, 283-293.

Spolek, G., 2008. Performance monitoring of three ecoroofs in Portland, Oregon. Urban Ecosystems 11, 349-359.

Stewart, I.D., Oke, T.R., 2012. Local Climate Zones for Urban Temperature Studies. Bulletin of the American Meteorological Society.

Taha, H., 2004. Heat islands and energy. In: Cleveland, C.J. (Ed.), Encyclopedia of Energy. Elsevier, Inc, New York.

Takebayashi, H., Moriyama, M., 2007. Surface heat budget on green roof and high reflection roof for mitigation of urban heat island. Building and Environment 42, 2971-2979.

Teemusk, A., Mander, U., 2010. Temperature regime of planted roofs compared with conventional roofing systems. Ecological Engineering 36, 91-95.

Teemusk, A., Mander, Ü., 2009. Greenroof potential to reduce temperature fluctuations of a roof membrane: A case study from Estonia. Building and Environment 44, 643-650.

Türkeri, N., Cem altun, M., Göçer, C., 2010. Field monitoring of thermal performance of a retrofit green roof in Istanbul, Turkey. Paper presented at the World Green Roof Congress, London, 2010.

UN, 2009. Available: <http://www.un.org/esa/population/publications/publications.htm> [accessed].

UOM, 2012. University of Manchester - The Whitworth Meteorological Observatory [online]. Available: <http:// www.cas.manchester.ac.uk/restools/whitworth/data/> [accessed March 2012].

Wilby, R.L., 2008. Constructing climate change scenarios of urban heat island intensity and air quality. Environment and Planning B-Planning \& Design 35, 902-919.

Wong, N.H., Chen, Y., Ong, C.L., Sia, A., 2003a. Investigation of thermal benefits of rooftop garden in the tropical environment. Building and Environment 38, 261-270.

Wong, N.H., Puay yok, T., Yu, C., 2007. Study of thermal performance of extensive rooftop greenery systems in the tropical climate. Building and Environment 42, 25-54.

Wong, N.H., Tay, S.F., Wong, R., Ong, C.L., Sia, A., 2003b. Life cycle cost analysis of rooftop gardens in Singapore. Building and Environment 38, 499-509. 